
\title{
CSResearch Square \\ Radiation therapy might help, not harm, cancer cells
}

\section{Nasrollah Jabbari \\ Muhammad Nawaz \\ Jafar Rezaie}

\section{Video Byte}

Keywords: VEGF, endothelial cells, radiation, cancer, therapy, tumor cells, bystander effects, angiogenesis, blood vessels

Posted Date: May 4th, 2020

DOl: https://doi.org/10.21203/rs.3.rs-27128/v1

License: (c) (i) This work is licensed under a Creative Commons Attribution 4.0 International License. Read Full License 


\section{Abstract}

Radiation therapy is a powerful way to kill cancer cells or slow their growth, but radiation can have unintended effects on surrounding cells. In a new study, researchers report that X-rays could actually help cancer cells gain a foothold in otherwise healthy tissue. The team blasted breast cancer cells cultured in the lab with different doses of X-rays. The cells released a cocktail of molecules in response including VEGF-A, a protein that triggers blood vessel formation. The team then transferred that molecular cocktail to healthy endothelial cells. Over time, those healthy cells showed a significantly enhanced ability to form the building blocks of blood vessels. This so-called "bystander effect" points to one way that cancer cells can cling to life even when zapped with radiation, and although the results are constrained to cells cultured in the lab, they could help inform researchers on how radiation therapy might do more harm than good. 